\title{
UJI EFEK ANTIINFLAMASI FRAKSI KLOROFORM DAUN JOHAR (Cassia siamea Lamk.) DENGAN METODE RAT HIND PAW EDEMA
}

\author{
Sitti Amirah, Hendra Herman \\ Fakultas Farmasi Universitas Muslim Indonesia Makassar \\ Email : irhae_banget@yahoo.co.id
}

\begin{abstract}
Johar (Cassia siamea Lamk.) leaves widely used as a traditional medicine. Johar leaves contain chemical compounds such us alkaloids, tannins, saponins, flavonoids, sitosterol and barakol which have effect of treatment for several diseases including inflammatory. This study aims to determine anti-inflammatory effect of chloroform fraction C.siamea leaves. This study was conducted using 15 Wistar rats were divided into 5 groups: control group who were given suspension of Na.CMC $1 \%$ $w / v$, the comparison group were given diclofenac sodium suspension $0.35 \mathrm{mg} / \mathrm{kg}$, the test group dose of $75 \mathrm{mg} / \mathrm{kg}$, the test group dose of $150 \mathrm{mg} / \mathrm{kg}$ and a test group of $300 \mathrm{mg} / \mathrm{kg}$. Evaluation of anti-inflammatory activity was done by measured initial volume of the foot all test animal then given the drug orally according to dosage of its group. After 30 minutes, each group made inflammatory by induced karagen $1 \% \quad 0.1 \mathrm{~mL}$ by intraplatar. Furthermore, inflammation's degrees was measured every hour for 8 hours. The results obtained show that after 2 hours, inflammatory of the control group Na.CMC had increased much higher compared to the other groups. This is shows that Na.CMC doesn't have effects anti-inflammation. The comparison group diclofenac sodium gave the best inhibitory effect that have been shown from an increase volume of feet smaller than the test group chloroform fraction of Johar leaves. While in chloroform fraction of Johar leaves test group, group with dosage $75 \mathrm{mg} / \mathrm{kg}$ gave an inhibitory effect better than the other test group dosage.
\end{abstract}

Key words : Johar leaves, Cassia siamea Lamk., anti-inflammatory.

\section{PENDAHULUAN}

Inflamasi atau yang biasa

disebut peradangan merupakan

kejadian yang umum dan sering

dialami oleh setiap individu. Inflamasi

merupakan salah satu respon normal

tubuh yang dapat disebabkan oleh

cedera, trauma fisik, zat kimia yang merusak, atau zat-zat mikrobiologi (Harvey, 2009). Inflamasi yang terjadi dapat bersifat akut ataupun kronis.Inflamasi akut terjadi dalam waktu singkat yang ditujukan untuk menghilangkan agen penyebab inflamasi dan membatasi jumlah jaringan yang rusak. Sedangkan 
Uji efek antiinflamasi fraksi kloroform daun johar (Cassia siamea Lamk.) dengan Metode Rat Hind Paw Edema

inflamasi kronik berlangsung lama dan dapat merupakan perkembangan dari inflamasi akut (Robbins and Cotran, 2010)

Berbagai macam obat sintetik telah dikembangkan untuk mengatasi masalah inflamasi. Obat-obat antiinflamasi yang ada saat ini umumnya memiliki efek samping yang besar. Saat ini ada 2 golongan obat yang digunakan sebagai antiinflamasi yaitu golongan steroid dan nonsteroid. Golongan steroid dapat menurunkan imunitas sedangkan nonsteroid dapat menyebabkan tukak lambung, gangguan ginjal, dll.

Banyaknya efek samping yang dapat ditimbulkan akibat penggunaan obat-obat sintetik,memicu pencarian obat alternatif yang berasal dari bahan alam atau yang lebih dikenal dengan obat tradisional. Penggunaan obat tradisionaldiharapkan memiliki tingkat keamanan dan efek samping yang lebih rendah dibanding obat sintetik.

Salah satu tanaman yang didugadapat memberikan efek antiinflamasi adalah daun johar (Cassia siamea L). Daun johar mengandung komponen kimia berupa alkaloid, saponin,tannin, flavonoid, barakol, sitosterol (Lakshmi, 2013). Kandungan flavonoid berupa flavon dan isoflavon inilah yang memiliki kemungkinan dapat memberikan efek antiinflamasi dengan menghambat aktivitas enzim siklooksigenase. Penghambatan jalur siklooksigenase secara langsung akan menghambat produksi prostaglandin yang merupakan salah satu mediator inflamasi (Robak,1996; Nijveldt et al.,2001). Daun johar telah diteliti oleh wahjoedi (1997) mengenai efek antipiretik ekstrak etanol daun johar pada tikus jantan dan mendapatkan hasil bahwa pada dosis $30 \mathrm{mg} / 100 \mathrm{grBB}$ dapat menurunkan demam.

Berdasarkan uraian diatas, maka akan dilakukan penelitian uji efek antiinflamasi fraksi kloroform daun johar dengan metode Rat Hind Paw Edema. Adapun perumusan masalah dari penelitian ini adalah apakah fraksi kloroform dari daun johar memiliki efek antiinflamasi. Tujuan dari penelitian ini adalah untuk menentukan efek antiinflamasi dan konsentrasi yang efektif dari fraksi kloroform daun johar dengan metode Rat Hind Paw Edema. Penelitian ini dilakukan untuk membuktikan bahwa kandungan kimia yang terkandung dalam tanaman memiliki efek antiinflamasi. Dengan luaran yang diharapkan dari penelitian ini adalah sebuah artikel ilmiah sehingga dapat 
Uji efek antiinflamasi fraksi kloroform daun johar (Cassia siamea Lamk.) dengan Metode Rat Hind Paw Edema

bernilai informatif dan inovatif dalam dunia farmasi untuk dikembangkan menjadi suatu produk fitofarmaka. Selain itu hasil yang diperoleh dapat memberikan informasi ilmiah kepada masyarakat tentang khasiat daun johar sebagai obat alternatif untuk inflamasi.

\section{METODE PENELITIAN}

\section{Alat dan bahan yang digunakan}

Alat-alat gelas, rotavapor (Like Werke Ika RV05), sonde oral, spoit, seperangkat alat maserasi, pletysmometer (Panlab LE 7500), timbangan hewan (Berke), timbangan analitik.

Air suling, etanol, kloroform, daun johar (Cassia siamea L.), Natrium CMC, pakan hewan, natrium diklofenak, karagen, $\mathrm{NaCl}$ 0,9\%.

\section{Prosedur Kerja}

\section{Pengambilan dan Pengolahan Sampel}

Sampel yang digunakan adalah daun johar (Cassia siamea Lamk.) yang diambil di Kota Makassar, Sulawesi Selatan.Daun diambil pada waktu pagi hari sekitar jam 10.00. sampel dibersihkan dari kotoran yang melekat dengan menggunakan air yang mengalir lalu dikeringkan dengan cara diangin-anginkan. Setelah kering sampel dihaluskan.

\section{Pembuatan Bahan Penelitian Pembuatan Ekstrak}

Ekstrak daun johar dibuat dengan metode maserasi yaitu sebanyak 300 gram dimasukkan dalam wadah maserasi kemudian ditambahkan etanol $70 \%$ hingga simplisia terendam sempurna, dibiarkan selama $1 \times 24$ jam dalam bejana tertutup dan terlindung dari cahaya sambil sesekali diaduk.Setelah itu simplisia disaring dan ampasnya direndam lagi dengan cairan yang baru hal ini dilakukan sampai seluruh komponen kimia tersari sempurna. Hasil penyarian yang didapat kemudian dikumpulkan dan di uapkan dengan menggunakan rotavapor hingga diperoleh ekstrak etanol yang kental (Depkes RI, 2010).

\section{Pembuatan Fraksi Kloroform}

Pembuatan fraksi kloroform dilakukan dengan cara ekstrak etanol yang telah diperoleh ditimbang sebanyak 5 gr kemudian dilarutkan dalam $50 \mathrm{ml}$ air suling. Setelah itu dimasukkan dalam corong pisah kemudian ditambahkan $20 \mathrm{ml}$ kloroform. Dilakukan pengocokan hingga komponen kimia melarut dalam pelarut kloroform.Setelah itu dilakukan pemisahan dengan mengeluarkan lapisan kloroform.Dilakukan secara berulang sampai lapisan kloroform bening. Hasil yang diperoleh 
Uji efek antiinflamasi fraksi kloroform daun johar (Cassia siamea Lamk.) dengan Metode Rat Hind Paw Edema

ditampung dan selanjutnya

dikeringkan.

Pembuatan larutan Koloidal Natrium

CMC 1\% b/v

Natrium CMC ditimbang sebanyak 1 gram kemudian dimasukkan sedikit demi sedikit kedalam $50 \mathrm{ml}$ air suling panas $\left(70^{\circ} \mathrm{C}\right)$ sambil diaduk dengan pengaduk elektrik hingga terbentuk larutan koloidal dan volume dicukupkan hingga $100 \mathrm{ml}$ sambil terus diaduk sampai homogen.

\section{Pembuatan Suspensi Natrium diklofenak 0,35 mg/kgbb}

Tablet natrium diklofenak sebanyak 10 tablet ditimbang, kemudian dihitung berat rata-rata tablet dan gerus. Serbuk yang telah digerus ditimbang sesuai hasil perhitungan kemudian disuspensikan dengan $\mathrm{Na} . \mathrm{CMC} 1 \%$ sedikit demi sedikit hingga homogen. Masukkan dalam labu ukur dan dicukupkan volumenya hingga $25 \mathrm{ml}$. Suspensi Natrium diklofenak dimasukkan dalam wadah yang tertutup rapat.

Pembuatan larutan karagen 0,1\% b/v

Ditimbang serbuk lamda karagen sebanyak $10 \mathrm{mg}$, kemudian dilarutkan dengan $\mathrm{NaCl}$ fisiologi sedikit demi sedikit hingga larut kemudian dicukupkan volumenya hingga $10 \mathrm{ml}$,

dimasukkan dalam wadah tertutup rapat.

\section{Pembuatan larutan uji}

Fraksi kloroform daun johar dibuat dalam 3 konsentrasi yaitu 75 $\mathrm{mg} / \mathrm{kgbb}, \quad 150 \mathrm{mg} / \mathrm{kgbb}$, dan 300 $\mathrm{mg} / \mathrm{kgbb}$. Untuk membuat dosis 75 $\mathrm{mg} / \mathrm{kgbb}$ yaitu ditimbang sebanyak $150 \mathrm{mg}$ (15 mg/200 gr mencit) kemudian di larutkan dalam $20 \mathrm{ml}$ NaCMC $1 \%$ b/v. Untuk membuat dosis $150 \mathrm{mg} / \mathrm{kgbb}$ dan $300 \mathrm{mg} / \mathrm{kgbb}$ masing-masing ditimbang $300 \mathrm{mg}$ dan $600 \mathrm{mg}$ yang dilarutkan dalam $20 \mathrm{ml}$ $\mathrm{NaCMC} 1 \% \mathrm{~b} / \mathrm{v}$.

\section{Persiapan dan aktimasi Hewan Uji}

Hewan uji yang digunakan dalam penelitian ini adalah tikus putih jantan galur wistar sebanyak 30 ekor dengan bobot badan 100-200 gram. Sebelum digunakan hewan uji diadaptasikan kurang lebih 7 hari (1 minggu) dan diberi pakan standar. Tujuan adaptasi untuk memastikan bahwa hewan uji sudah beradaptasi dengan baik dan siap untuk digunakan dalam penelitian dan untuk meminimalisasi sumber keragaman yang dapat mempengaruhi validitas data.

\section{Perlakuan Hewan Uji}

Hewan uji yang telah diadaptasikan diukur volume kaki awal kemudian dibagi menjadi 6 kelompok yang sebelumnya telah dipuasakan 
Uji efek antiinflamasi fraksi kloroform daun johar (Cassia siamea Lamk.) dengan Metode Rat Hind Paw Edema

selama 8-16 jam. Hewan uji diberikan perlakuan secara oral dimana kelompok 1 sebagai kelompok normal, kelompok 2 sebagai kontrol yang diberi suspensi NaCMC $1 \%$ b/v, kelompok 3 sebagai pembanding yang diberi suspensi Natrium diklofenak $0,35 \mathrm{mg} / \mathrm{kg} \mathrm{bb}$, kelompok 4, 5 dan 6 sebagai kelompok uji dosis $75 \mathrm{mg} / \mathrm{kg}$ bb, kelompok uji dosis $150 \mathrm{mg} / \mathrm{kg}$ bb dan kelompok uji $300 \mathrm{mg} / \mathrm{kg}$ bb.Tiga puluh menit setelah pemberian larutan uji dilakukan penyuntikan larutan lamda karagen $1 \%$ pada telapak kaki kiri tikus sebanyak 0,1 ml. Penyuntikan karagen dilakukan secara intraplantar. Satu jam kemudian dilakukan pengukuran volume kaki setelah penyuntikan menggunakan alat pletismometer dengan cara mencelupkan kaki kiri tikus ke dalam alat pletismometer sampai batas tanda dan dicatat. Pengukuran selanjutnya dilakukan tiap jam selama 8 jam (Narande, 2013).

\section{HASIL PENELITIAN}

\begin{tabular}{|c|c|c|c|c|c|c|c|c|c|}
\hline \multirow{3}{*}{ Perlakuan } & \multicolumn{9}{|c|}{ Volume kaki (mL+SD) } \\
\hline & \multirow{2}{*}{ Awal } & \multicolumn{8}{|c|}{ Setelah terapi dan induksi } \\
\hline & & 1 & 2 & 3 & 4 & 5 & 6 & 7 & 8 \\
\hline Na Diklofenak & $\begin{array}{c}2,40 \pm \\
0,02\end{array}$ & $\begin{array}{c}2,63 \pm \\
0,23\end{array}$ & $\begin{array}{c}3,08 \pm \\
0,58\end{array}$ & $\begin{array}{c}2,89 \pm \\
0,37\end{array}$ & $\begin{array}{c}3,44 \pm \\
0,20\end{array}$ & $\begin{array}{c}2,96 \pm \\
0,41\end{array}$ & $\begin{array}{c}3,35 \pm \\
0,36\end{array}$ & $\begin{array}{c}2,89 \pm \\
0,56\end{array}$ & $\begin{array}{c}2,51 \pm \\
0,24\end{array}$ \\
\hline $\mathrm{Na} \mathrm{CMC}$ & $\begin{array}{c}2,85 \pm \\
0,03\end{array}$ & $\begin{array}{c}3,32 \pm \\
0,21\end{array}$ & $\begin{array}{c}4,70 \pm \\
0,95\end{array}$ & $\begin{array}{c}5,51 \pm \\
1,31\end{array}$ & $\begin{array}{c}5,98 \pm \\
1,03\end{array}$ & $\begin{array}{c}6,16 \pm \\
0,86\end{array}$ & $\begin{array}{c}5,30 \pm \\
0,43\end{array}$ & $\begin{array}{c}5,26 \pm \\
0,75\end{array}$ & $\begin{array}{c}5,48 \pm \\
0,93\end{array}$ \\
\hline $\begin{array}{l}\text { Ekstrak Dosis } 75 \\
\mathrm{mg} / \mathrm{kg} \text { BB }\end{array}$ & $\begin{array}{c}1,57 \pm \\
0,05\end{array}$ & $\begin{array}{c}2,17 \pm \\
0,60\end{array}$ & $\begin{array}{c}2,96 \pm \\
0,33\end{array}$ & $\begin{array}{c}3,79 \pm \\
0,33\end{array}$ & $\begin{array}{c}3,36 \pm \\
0,47\end{array}$ & $\begin{array}{c}2,71 \pm \\
0,11\end{array}$ & $\begin{array}{c}2,65 \pm \\
0,08\end{array}$ & $\begin{array}{c}2,66 \pm \\
0,21\end{array}$ & $\begin{array}{c}2,36 \pm \\
0,31\end{array}$ \\
\hline $\begin{array}{l}\text { Ekstrak Dosis } \\
150 \mathrm{mg} / \mathrm{kg} \mathrm{BB}\end{array}$ & $\begin{array}{c}1,90 \pm \\
0,02\end{array}$ & $\begin{array}{c}1,83 \pm \\
0,30\end{array}$ & $\begin{array}{c}3,07 \pm \\
0,23\end{array}$ & $\begin{array}{c}3,54 \pm \\
0,15\end{array}$ & $\begin{array}{c}4,16 \pm \\
0,63\end{array}$ & $\begin{array}{c}4,36 \pm \\
0,81\end{array}$ & $\begin{array}{c}3,76 \pm \\
0,98\end{array}$ & $\begin{array}{c}4,06 \pm \\
1,35\end{array}$ & $\begin{array}{c}4,16 \pm \\
1,08\end{array}$ \\
\hline $\begin{array}{l}\text { Ekstrak Dosis } \\
300 \mathrm{mg} / \mathrm{kg} \text { BB }\end{array}$ & $\begin{array}{c}2,00 \pm \\
0,05\end{array}$ & $\begin{array}{c}2,19 \pm \\
0,13\end{array}$ & $\begin{array}{c}2,89 \pm \\
0,43\end{array}$ & $\begin{array}{c}3,64 \pm \\
0,14\end{array}$ & $\begin{array}{c}3,30 \pm \\
0,51\end{array}$ & $\begin{array}{c}3,68 \pm \\
0,26\end{array}$ & $\begin{array}{c}3,62 \pm \\
0,41\end{array}$ & $\begin{array}{c}3,75 \pm \\
0,15\end{array}$ & $\begin{array}{c}3,32 \pm \\
0,34\end{array}$ \\
\hline
\end{tabular}

\section{PEMBAHASAN}

Dari hasil penelitian yang telah dilakukan, maka diperoleh data pengukuran volume radang pada telapak kaki tikus sebelum dan setelah perlakuan. Pada gambar 1 dapat dilihat bahwa setelah penyuntikan karagen secara intraplantar terjadi peningkatan volume kaki secara perlahan. Hal ini menunjukkan bahwa penyuntikan karagen dapat menyebabkan peradangan. Radang terjadi karena karagen merupakan suatu zat asing (antigen), jika masuk kedalam tubuh akan merangsang antibodi untuk melawan antigen. Karagen akan merangsang lisisnya sel mast dan melepasakan mediatormedator inflamasi yang dapat menyebabkan vasodilatasi sehingga terjadi eksudasi pada dinding kapiler dan migrasi fagosit ke daerah radang 
Uji efek antiinflamasi fraksi kloroform daun johar (Cassia siamea Lamk.) dengan Metode Rat Hind Paw Edema

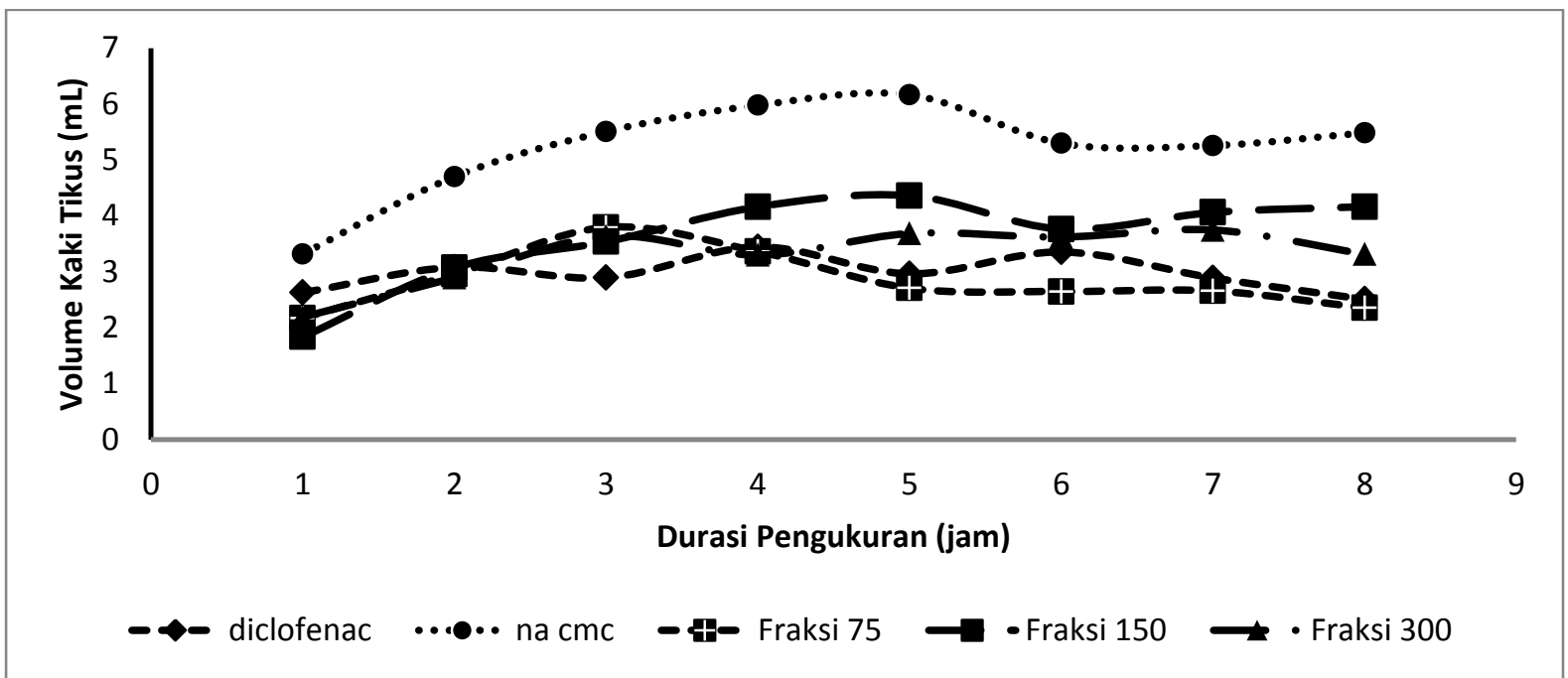

Gambar 1. Grafik perubahan volume kaki setelah pemberian ekstrak dan induksi

Pada penelitian ini, dilakukan pengujian efek antiinflamasi terhadap fraksi kloroform daun johar dengan 3 variasi dosis. Hal ini dilakukan untuk mengetahui dosis efektif yang dapat memberikan efek penghambatan inflamasi terhadap hewan uji tikus. Selain itu dilakukan juga pengujian menggunakan pembanding obat dan kontrol pelarut. Pengujian menggunakan pembanding obat dilakukan untuk membandingkan efek yang ditimbulkan oleh obat dan fraksi uji. Pengujian kontrol pelarut dilakukan untuk mengetahui adanya kemungkinan efek yang dapat ditimbulkan oleh kontrol.

Peningkatan volume kaki yang terjadi secara perlahan menunjukkan adanya efek penghambatan inflamasi dari kelompok uji. Hal itu dapat dilihat pada gambar 1 bahwa kelompok kontrol NaCMC mengalami peningkatan inflamasi yang jauh lebih tinggi mulai jam ke-2 dibanding kelompok uji yang lain. Hal ini menunjukkan bahwa NaCMC tidak memiliki efek penghambatan inflamasi sehingga dapat diketahui bahwa efek penghambatan pada kelompok uji adalah murni berasal dari komponen kimia dari fraksi yang diujikan bukan dari pelarut yang digunakan.

Pada gambar 1 memperlihatkan bahwa kelompok pembanding natrium diklofenak memberikan efek penghambatan yang paling baik terlihat dari peningkatan volume kaki yang kecil dibanding kelompok uji fraksi daun johar. Natrium diklofenak bekerja terutama melalui inhibisi biosintesa prostaglandin dengan 
Uji efek antiinflamasi fraksi kloroform daun johar (Cassia siamea Lamk.) dengan Metode Rat Hind Paw Edema

menghambat kerja enzim

siklooksigenase-1

dan

siklooksigenase-2. Siklooksigenase

merupakan enzim yang

bertanggungjawab terhadap

biosintesis prostaglandin yang

merupakan salah satu mediator inflamasi (Robert and Morrow, 2008).

Kelompok uji fraksi daun johar untuk semua dosis memperlihatkan penghambatan yang baik sampai pada jam ke-2, tetapi pada jam ke-3 efek penghambatan sudah mulai berkurang terlihat dari peningkatan volume kaki yang semakin besar. Dosis $75 \mathrm{mg} / \mathrm{kg}$ memperlihatkan penurunan volume radang yang lebih cepat dan stabil yaitu mulai pada jam ke-4. Sementara kelompok uji dengan dosis yang lebih tinggi memperlihatkan penurunan volume radang yang fluktuatif.

Dari hasil analisa menunjukkan bahwa fraksi daun johar dengan dosis yang lebih rendah memberikan efek penghambatan inflamasi yang lebih baik dibanding dosis yang lebih besar. Hal ini mungkin disebabkan karena fraksi yang diuji masih mengandung banyak komponen yang dapat saling berinteraksi dan menekan efek inflamasi, sehingga dengan meningkatnya dosis akan semakin meningkatkan jumlah zat dari masingmasing komponen yang dapat menimbulkan interaksi yang semakin besar pula.

\section{KESIMPULAN}

Berdasarkan hasil analisis dapat disimpulkan bahwa fraksi kloroform daun johar dapat memberikan efek penghambatan inflamasi pada dosis $75 \mathrm{mg} / \mathrm{kg} \mathrm{BB}$.

\section{DAFTAR PUSTAKA}

Amirah, S., Kosman, R., Novianti, Y. R., 2014. Uji Efek Antiinflamasi Ekstrak n-butanol dan Etil asetat Daun Petai Cina (Leucaena leucocephala (Lamk.) de Wit) Terhadap Mencit Jantan Yang Di induksi Dengan Karagen. Jurnal Bionature 15(2).

Depkes RI. 2008. Suplemen I Farmakope Herbal Indonesia. Jakarta

Harvey, R.A., Champe, P.C., 2009. Farmakologi Ulasan Bergambar. Penerbit Buku Kedokteran EGC, Jakarta.

Lakshmi, Gangan, R.B., Ravi, K., 2013. Evaluation of In Vitro Antibacterial Activity of Cassia siamea Leaves. ISSN: 09751491

Narande, J.M., Wulur, A., Yudistira, A., 2013. Uji efek antiinflamasi ekstrak etanol daun suji (Dracaena angustifolia Roxb) terhadap edema kaki tikus putih jantan galur wistar, Pharmacon Jurnal IImiah Farmasi UNSRAT2(3).

Nijveldt, R J., E. van Nood, D.E.C., Van hoom, P.G., Boelens,K van Norren, P.A.M van 
Uji efek antiinflamasi fraksi kloroform daun johar (Cassia siamea Lamk.) dengan Metode Rat Hind Paw Edema

Leeuwen., 2001. Flavonoids: a review of probable mechanisms of action and potential aplpications. American journal of clinical and Nutrition 74.

Robak, J., Gryglewsk,i RJ., 1996. Bioactivity of flavonoids. Polish journal of Pharmacology 48(6).

Robbins and Cotran. 2010. Pathologic Basic of Disease $8^{\text {th }}$.
Elsevier's Health Sciences

Rights Departement in Philadelphia, PA, USA.

Robert, L.J., Morrow, J.D., 2008. Dasar Farmakologi Terapi edisi 10, Penerbit Buku Kedokteran EGC, Jakarta.

Wahjoedi, B., 1997. Efek antipiretik ekstrak etanol daun johar (Cassia siamea L.) pada tikus putih. 